Dejan Živkov ${ }^{1}$,

Jovan Njegić ${ }^{2}$,

Jelisaveta Markelić ${ }^{3}$
JEL: C21, F31, G15

DOI: 10.5937/industrija42-5561

UDC: 339.743:336.763.2(4-773)

330.45:519

Original Scientific Paper

\title{
Exchange Rate Effect on Stock Returns in the East European Emerging Markets - A Quantile Regression Approach
}

Article history:

Received: 22 February 2014

Sent for revision: 26 February 2014

Received in revised form: 14 July 2014

Accepted: 30 July 2014

Available online: 1 November 2014

Abstract: This paper investigates relationship between returns of stock prices and exchange rate changes in four East European emerging markets (Serbia, Poland, Hungary and Czech Republic) using weekly data from January 2003 to June 2013. Two theories explain the connection in the economic literature flow-oriented and portfolio-balance models, without a finite and conclusive answer on which one is predominant. Considering our relatively large sample period which also includes world crisis outbreak, the used empirical data have been compromised by structural breaks and heterogeneous unconditional distribution. To avoid parameter bias and wrong conclusions, authors used four auto-regressive distributed lag $A D L(2,2)$ models assessed with quantile regression method, robust to non-normality problems. The results indicate that relationship between these variables is in accordance with portfoliobalance models in three out of four analyzed countries.

Keywords: Exchange rate, stocks, quantile regression, East European countries

\section{Uticaj deviznog kursa na stopu prinosa akcija u istočno- evropskim zemljama u razvoju- pristup preko kvantilne regresije}

Apstrakt: Ovaj rad istražuje vezu između stopa prinosa akcija i promena deviznog kursa u četiri istočno-evropske zemlje (Srbiji, Poljskoj, Mađarskoj i

\footnotetext{
${ }^{1}$ Business school of Novi Sad, dejanzivkov@gmail.com

${ }^{2}$ Lecturer, Business school of Novi Sad

${ }^{3}$ Student of specialist studies at Business school of Novi Sad 
Živkov D. et al.: Exchange Rate Effect on Stock Returns in the East...

Češkoj) upotrebljavajući nedeljne podatke od januara 2003 do juna 2013. U ekonomskoj literaturi dve teorije objašnjavaju tu vezu - model na bazi toka i medel ravnotežnog portfolio, međutim bez konačnog i definitivnog zaključka koja teorija preovlađuje. Uzimajući u obzir relativno širok uzorak koji obuhvata i period svetske ekonomske krize, empirijski podaci koji su upotrebljeni su kompromitovani zbog prisustva strukturnih lomova i empirijske raspodele koja nije normalna. Kako bismo izbegli pristrasnost ocenjenih parametara i pogrešne zaključke, autori su opotrebili četiri $\operatorname{ADL}(2,2)$ modela ocenjena uz pomoć metode kvantilne regresije koja je otporna na problem raspodele koja ne prati normalnu distribuciju. Rezultati ukazuju da je veza između tih varijabli u skladu sa modelom ravnotežnog portfolio u tri od četiri analizirane zemlje.

Ključne reči: Devizni kurs, akcije, kvantilna regresija, Istočno Evropske zemlje.

\section{Introduction}

After transition process initiation, most East European transition countries, such as Serbia, Poland, Czech Republic and Hungary, decided to switch toward more flexible exchange rate policy after initial choice of fixed regime. Due to significant economic growth, gradual disinflation and the liberalization of capital account, those countries underwent fairly large capital inflows (Caballero et al., 2008). However, if country has moderate absorption capacities for entering capital, those flows for recipient economy will eventually cause serious problems as high money growth, inflationary expectation pressures and unstable exchange rate. Consequently, some East European emerging countries have started to modify their exchange rate regimes toward more floating or with wider bands along with the adoption of inflation targeting strategy. For instance, since political changes in October 2000 , exchange rate was used as a nominal anchor in a conventional fixed peg regime until January 2003 in Serbia. However, very soon nominal dinar/euro exchange rate started to depreciate since January 2003. Savić and Bošković (2011) asserted that abundant capital inflows lead to higher economic growth, higher consumption from import and appreciation of the domestic currency. Dinar appreciation happened in Serbia in period 20062007. However, after world crisis outbreak and due to constant negative pressures on dinar, monetary authorities in Serbia decided to change exchange rate strategy toward managed floating exchange rate regime and inflation targeting in January 2009. As for Czech Republic, since the late 1990 's, the Czech national bank has been applying inflation targeting combined with a floating exchange rate regime. National bank of Hungary (MNB) applied mixed regime that includes inflation targeting with a unilateral peg of the forint to the euro, with a fluctuation band of $+/-15 \%$ between mid- 
2001 and early 2008. Also, Poland operates a floating exchange rate regime since April 2000. Generally, despite many advantages, floating regimes could have negative repercussions for the economy. Especially, it refers to its greater instability comparing to pegged regimes. High volatility currencies could have substantial influence on other assets' prices. Therefore, this paper explores how and if erratic behavior of floating exchange rate influence the stock prices in Serbia, Poland, Czech Republic and Hungary.

Additionally, it is well known fact that most long range series in finance characterize non-linear and irregular behavior typically induced by multiple structural breaks or by outliers' presence. These problems could harm model adequacy, create parameter bias and wrong conclusions. Elegant bypass on this issue could be the usage of methods that are especially designed to tackle non-linearity. In the following chapters authors utilize quantile regression (QR) method with aim to thoroughly investigate whether and how exchange rate changes affect stock returns in these countries.

The reminder of this paper is organized as follows. Chapter 2 discusses literature review and theoretical approach about interaction between exchange rate and stocks. Chapter 3 introduces research methodology, defines the data and gives some preliminary tests. Chapter 4 considers the results and chapter 5 concludes.

\section{Literature review}

Although a debate on the connections between the exchange rate and stock prices has been going over the past several decades, economic theory still does not have a unique stance about how stock and exchange market interact. The reasons could be found in various macroeconomic conditions that shape every country, e.g. the size of economy, its openness and level of capital inflow, overall economic development, the extent of stock and currency market interconnection, etc. The classical economic theory proposes two ways of interaction: 'flow oriented' model and portfolio-balance model. The flow oriented approach asserts that exchange rate changes (e.g. depreciation) affect international competitiveness which consequently reflects on the balance of trade position. The increase of the real output in the country influences current and future cash flows of companies, especially those export-oriented, which make their stock prices raise. This is an indirect linkage and the copula is balance of trade. The other theory, portfolio-balance approach, bases its connection on demand and supply for financial assets. The increased demand for domestic stocks will result in higher requirements for domestic currency, which would eventually lead to its appreciation. The portfolio-balance model advocates a direct relationship between these two variables. Some empirical evidence supported the flow-oriented hypothesis 
Živkov D. et al.: Exchange Rate Effect on Stock Returns in the East...

(see Fang, 2002; Phylaktis and Ravazzolo, 2005; Moore and Wang, 2014) while others favored the stock-oriented assumption (Tai, 2007; Walid et al. (2011), Liang et al., 2013). The paper endeavors to determine which of the mentioned theories is more suitable for Serbian, Polish, Czech and Hungarian markets. Accordingly, the positive (negative) sign coefficients stand in front of exchange rate changes if priority has flow-oriented (portfolio balance) model.

Fang (2002) investigated the effects of currency depreciation on stock returns and its volatility in the five East Asian economies, namely: Hong Kong, Singapore, South Korea, Taiwan and Thailand over the period of the Asian crisis 1997-1999. He showed that domestic currency depreciation not only decreases the mean stock return but also increases stock market volatility. Phylaktis and Ravazzolo, 2005 studied the long-run and short-run dynamics between stock prices and exchange rates using cointegration methodology and multivariate Granger causality tests on a group of Pacific Basin countries over the period 1980-1998. The findings suggested that stock and foreign exchange markets are positively related in accordance with flow-oriented model. The study of Moore and Wang (2014) revealed that in countries with a relatively low degree of capital mobility, economic integration is likely to be the main force of the connection, which stands in line with flow-oriented approach. They used dynamic conditional correlation (DCC) methodology on several developed and emerging Asian markets. On the contrary, according to same authors, in countries with the high capital mobility, financial integration is the main cause that favored the stock-oriented model.

The findings of Liang et al. (2013) stand in line with the Moore and Wang (2014) statement. They used panel Granger causality and panel DOLS methodologies on ASEAN-5 countries and found support for the stockoriented hypothesis. They argued that exchange rates impact stock prices negatively via capital mobility. The study of Tai (2007) disclosed that dynamic relationship between stock and foreign exchange markets is consistent with stock or portfolio-balance theory for six Asian countries. In the study, he tested a dynamic integrated international capital asset pricing model (ICAPM), embedding it in an asymmetric multivariate $\operatorname{GARCH}(1,1)$-in-Mean model. In another study, Walid et al. (2011) using hidden Markov EGARCH model on four Asian countries (Hong Kong, Singapore, Malaysia and Mexico) found support for portfolio-balance approach because exchange rate has negative sign in mean equation for all four countries. They also concluded that volatility on exchange market reduces stock market returns.

Considering the mixing results, further tests need to be conducted regarding this issue, in order to help in comprehension of its elaborate relation. Having this in mind, authors test the following hypothesis:

$H_{0}$ : Exchange rate changes influence stock return dynamics in Serbia, Poland, Czech Republic and Hungary according to portfolio-balance theory. 
Živkov D. et al.: Exchange Rate Effect on Stock Returns in the East...

\section{Research methodology and data}

\subsection{Quantile regression approach}

This paper strives to determine the relationship between FX (foreign exchange) and stock market on a selected group of countries. In order to avoid possible autocorrelation bias authors decided to use general form of auto-regressive distributed lag $(\operatorname{ADL}(p, q))$ specification, since these two variables are dynamically correlated.

$r_{n, t}=\mu_{n, t}+\sum_{i=1}^{p} \alpha_{i} r_{n, t-i}+\sum_{j=0}^{q} \beta_{k} S_{n, t-j}+\varepsilon_{n, t}$

where $r_{n, t}=100 \times \ln \left(P_{n, t} / P_{n, t-1}\right)$ is defined as index rate of return for the stock market $(n)$ at time $(t)$ and $P_{n, t}$ is stock price of specific index (n). The $S_{n, t}=100 \times \ln \left(F X_{n, t} / F X_{n, t-1}\right)$ represents the exchange rate changes of regarding currency $(n)$ at time $(t)$. $F X_{n, t}$ indicates exchange rate value of currency (n). $\mu_{n}$ is a constant, while $\alpha$ and $\beta$ are parameters to be estimated.

A common empirical approach would be assumption that above model has normal distribution, i.e. $\varepsilon_{n, t} \sim N\left(0, \sigma_{n, t}^{2}\right)$. However, authors omitted normality postulation because of the fact that observed time span encompasses world economic crisis outbreak at 2007 and that analysis deals with the volatile emerging markets, which could lead to the violation of that assumption and the key conjecture of constant elasticity specification. Common knowledge says that model estimated with OLS using data polluted with multiple structural breaks and various outliers could lead to significant parameter bias and produce erroneous conclusions. The application of least squares estimator under the presence of outliers could produce large residuals, which squared values could cause biased estimates and greater weight of assessed parameters. As Koenker and Halloc (2001) mention, every attempt to chop the sample into high, medium and low values of $Y$ and then running an OLS on the every subset is not a solution, since it would generate sample selection bias. However, some authors as Miles and Schreyer (2012), Sula (2011), Lin and Chu (2013) circumvented the problem using a quantile regression method. In the paper, authors also followed this methodology. This particular method is an extension of OLS estimation of the conditional mean. It is a method robust to outliers and allows heterogeneous impact of independent variables at different points of dependent variable distribution, i.e. it generates a stack of models for variant conditional quantile functions. The QR (quantile regression) initiates specification with the conditional quantile as a linear function of various explanatory variables which is defined as: 
Živkov D. et al.: Exchange Rate Effect on Stock Returns in the East...

$Y_{t}=X_{t}^{\prime} \beta+\varepsilon_{t}$

$Q_{\tau}(Y \mid X=x)=x^{\prime} \beta(\tau)$

where $\mathrm{Y}$ is a dependant variable, $\mathrm{X}$ is a vector of explanatory variables, $\varepsilon$ is an error term which distribution is intentionally left unspecified because it only assume that $\varepsilon$ fulfill quantile restriction: $Q_{\tau}(\varepsilon \mid X=x)=0$. The expression $Q_{\tau}(Y \mid X=x)$ labels the $\tau$-th quantile of $Y$ is conditional on $X=x$. The value $\beta(\tau)$ measures the speed of mean reversion of $Y$ within each quantile and particular QR estimate $(\hat{\beta}(\tau))$ is the solution to the following minimization problem:

$\min _{\beta \in R^{p}}\left[\tau \sum_{Y_{t} \geq \hat{\beta} X_{t}}\left|Y_{t}-\hat{\beta} X_{t}\right|+(1-\tau) \sum_{Y_{t}<\hat{\beta} X_{t}}\left|Y_{t}-\hat{\beta} X_{t}\right|\right]$

If $\tau=0.5$ the procedure (4) yield the median regression. By running quantile regression estimation by increasing tau $(\tau)$ continually from 0 to 1 , one can follow dependant variable distribution, conditional on explanatory variables, and gain thorough view on effects between $Y$ and $X$, comparing to OLS estimation. Specification of $\operatorname{ADL}(p, q)$ model under $Q R$ estimation looks like:

$r_{n, t}=\mu_{n, t}+\sum_{i=1}^{p} \alpha_{i}(\tau) r_{n, t-i}+\sum_{j=0}^{q} \beta_{k}(\tau) S_{n, t-j}+\varepsilon_{n, t}$

where $\alpha(\tau), \beta(\tau)$ are parameters at the $\tau$-th quantile, i.e. vectors of autoregressive components and (legged) explanatory variables. In the following section, the various preliminary tests are presented in order to gain insight in relation between exchange rate and stocks, as well as to look for nonnormality evidence which would justify the utilization of QR method.

\subsection{Data description and preliminary results}

Data set used in the paper comprise weekly observations of four stock indices - BELEX LINE (Belgrade stock exchange), MWIG40 (Warsaw stock exchange), PX (Prague stock exchange) and BUX (Budapest stock exchange) and their related currencies - dinar, zloty, koruna and forint. The observed period ranges from January 2003 to June 2013 for all series except for BELEX LINE and dinar. For these two series starting date is October 2004 due to non-existent data before that particular date.

The Figure 1 displays values of weekly observed series dynamics and could help in gaining preliminary comprehension about the possible relation between two variables. The key question is whether flow-oriented or portfolio 
Živkov D. et al.: Exchange Rate Effect on Stock Returns in the East...

balance approach has predominance in these economies. A direct correlation between particular exchange rate and stocks would point to flow-oriented relationship, while inverse causality would indicate portfolio balance approach. Looking at Figure 1, an initial conclusion would be that observed variables possess dynamics in accordance with portfolio balance theory. Therefore, the appreciation (depreciation) of exchange rate would lead to the increase (decrease) of stock prices. The visual approach suggests the negative sign of the slope coefficients.

Figure 1. Historical time series of stock indices and exchange rates

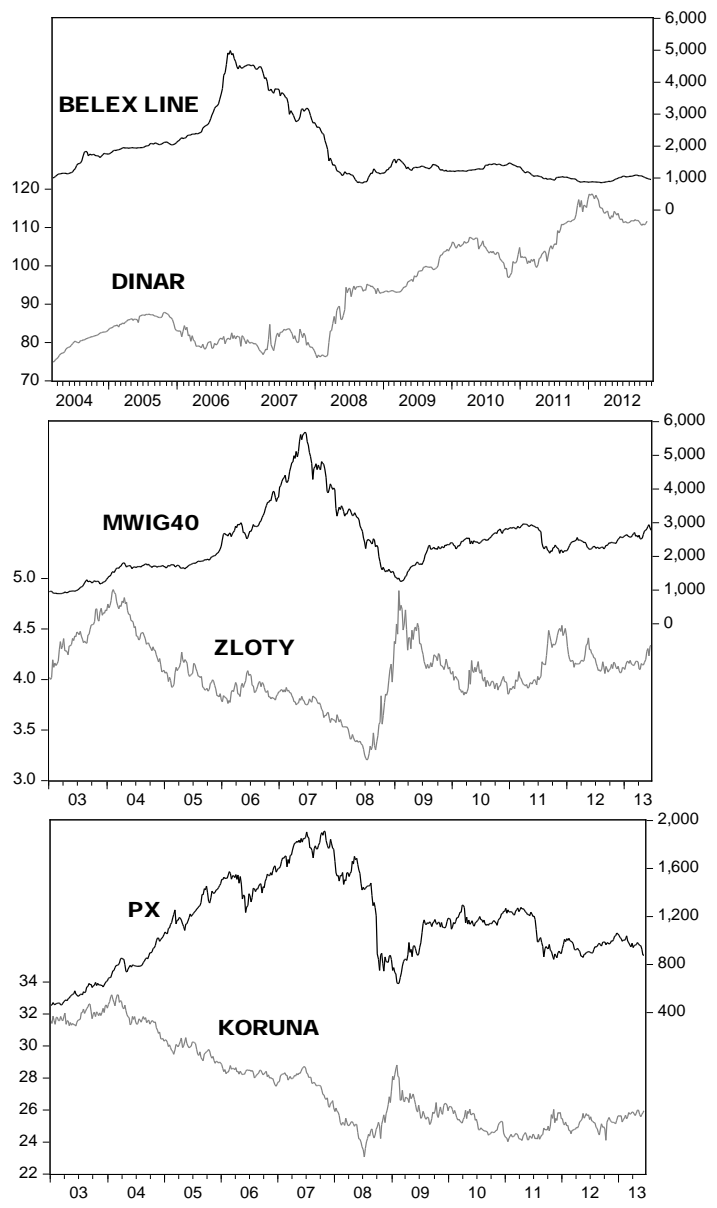


Živkov D. et al.: Exchange Rate Effect on Stock Returns in the East...

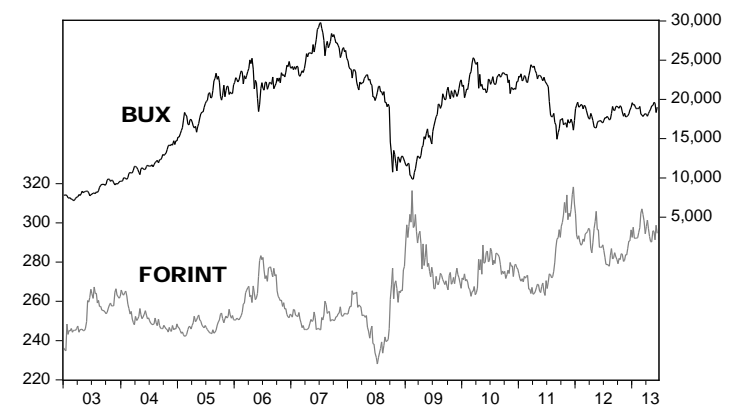

Source: Authors' calculation

Likewise, in Table 1, Panel A, the results of Granger causality test with five lags have been plotted which should give first glimpse whether exchange rate changes influence stock returns. Table 1, Panel A reveals mixing results. In Serbia, Poland and Hungary the p-values are small enough to suggest that exchange rate dynamics cause changes in stock prices. In the Czech Republic that relation is not present. Panel B, Table 1 uncovers the nature of unconditional distribution of dependent variables, as well as their unit root tests. It introduces some succinct summary statistics of returns of observed series; first four moments, median value, augmented Dickey-Fuller unit-root test, and Jarque-Bera test of normality.

Table 1. Granger causality and summary statistics for selected indices

\begin{tabular}{|c|c|c|c|c|c|c|c|}
\hline \multicolumn{8}{|l|}{ Panel A } \\
\hline \multicolumn{4}{|c|}{ Granger causality test } & \multicolumn{2}{|c|}{ F-stat. } & \multicolumn{2}{|c|}{ p-value } \\
\hline \multicolumn{4}{|c|}{ Dinar does nor Granger cause BELEX LINE } & \multicolumn{2}{|c|}{2.421} & \multicolumn{2}{|c|}{0.0351} \\
\hline \multicolumn{4}{|c|}{ Forint does not Granger cause BUX } & \multicolumn{2}{|c|}{29.531} & \multicolumn{2}{|c|}{$2 . E-26$} \\
\hline \multicolumn{4}{|c|}{ Koruna does not Granger cause PX } & \multicolumn{2}{|c|}{1.292} & \multicolumn{2}{|c|}{0.2660} \\
\hline \multicolumn{4}{|c|}{ Zloty does not Granger cause MWIG40 } & \multicolumn{2}{|c|}{4.512} & \multicolumn{2}{|c|}{0.0005} \\
\hline \multicolumn{8}{|c|}{ Panel B } \\
\hline $\begin{array}{l}\text { Observed } \\
\text { series }\end{array}$ & Mean & Median & S.D. & Skew. & Kurt. & ADF test & $\begin{array}{c}\text { JB } \\
\text { stat. } \\
\text { (p-value) }\end{array}$ \\
\hline BELEX LINE & 0.036 & 0.119 & 3.021 & -0.118 & 8.722 & $-7.579^{a}$ & 0.000 \\
\hline MWIG40 & 0.239 & 0.472 & 2.878 & -0.799 & 5.908 & $-18.856^{\mathrm{a}}$ & 0.000 \\
\hline $\mathrm{PX}$ & 0.180 & 0.327 & 3.342 & -0.896 & 12.495 & $-10.247^{a}$ & 0.000 \\
\hline$B \cup X$ & 0.238 & 0.317 & 3.757 & -0.204 & 10.914 & $-22.789^{a}$ & 0.000 \\
\hline
\end{tabular}

Source: Authors' calculation

The findings suggest that all series express significant erratic behavior. Stock indices are all left-skewed which indicate that median is larger than mean, i.e. left tail of the distribution is longer than right one. Despite positive mean 
values, which indicate positive results for investors on average yield, negative skewness points to more negative data concentrated around the mean value. It also implies that distribution bear extreme values, which is corroborated by large excess kurtosis coefficients. The explanation of the presence of leptokurtosis could be that selected indices probably contain outliers.

Extreme dynamics of all series is pooled together in very low level of JarqueBera p-value, indicating severe non-normality. For that reason, quantile regression method could be very handy because of its robustness to extreme values. ADF test confirmed that all series strongly reject null hypothesis of unit root presence, so spurious regression should not be at concern.

In addition to non-normal manner of empirical series, authors also check for the presence of structural breaks. If that assumption is proved to be correct, preference for quantile regression method would be further justified. Ordinary regressions could produce biased parameters due to structural change, while this problem could be elegantly circumvented by quantile regression approach. It should be noted that structural breaks are more susceptible to financial macro-series of emerging markets because they are less capable to buffer unexpected shocks. For that reason authors utilize method constructed by Bai and Perron (2003) known as sequential tests of $l+1$ versus $l$ globally determined breakpoints. This process of assessing the number of existing breaks is applied sequentially, beginning with a single break, until the null is not rejected. Two procedures were considered - UDmax and WDmax tests. The specific break dates for every series could be found in Table 2. Applied procedures indicate that Polish and Hungarian indices contain two breaks and Serbian index one. For Czech index no breaks were found whatsoever. It is obvious that world crisis caused one structural shift in BELEX LINE, MWIG40 and BUX index. Given the fact that all series exhibit erratic behavior and nonnormality features with the presence of break (in some cases several), a quantile regression analysis would be appropriate method to avoid potential parameter bias.

Table 2. Break dates with UDmax and WDmax critical values

\begin{tabular}{|c|c|c|c|}
\hline BELEX LINE & MWIG40 & BUX & PX \\
\hline 10/03/2008 & $08 / 11 / 2006$ & $23 / 08 / 2006$ & \\
UDmax stat. & $25 / 06 / 2008$ & $03 / 12 / 2008$ & - \\
22.96 & UDmax stat. 47.59 & UDmax stat. 30.01 & \\
WDmax stat. 25.36 & WDmax stat. 55.01 & WDmax stat. 35.85 & \\
\hline \multicolumn{2}{|l}{ UDMax critical value 20.30; WDMax critical value 21.86 } \\
\hline
\end{tabular}

Source: authors' calculation 
Živkov D. et al.: Exchange Rate Effect on Stock Returns in the East...

\section{Research results}

In order to investigate how exchange rate changes affect stock return, authors plotted four $\operatorname{ADL}(2,2)$ models assessed with QR inferential procedure and OLS in order to measure degree of influence at different level of dependant variables. The results are reported in Table 3 and Table 4.

It could be noticed that statistically significant parameters in front of exchange rate changes have negative sign in three out of four panels, which implies goodness of fit of portfolio balance model on Serbian, Polish and Hungarian economies. As for the Serbian index, first lag autoregressive parameters are all significant at relatively high level. All parameters hover around approximately equal values, which means that stock market information from the previous period considerably influence current index dynamics in tranquil as well as in more erratic periods. For the second lag of BELEX LINE, the information transfer happens only at the lowest quantiles. Dinar/Euro exchange rate changes affect Serbian index contemporaneously, as well as at first lag. However, the contemporaneous effect is more intense compared to first lag effect and it happens up to 6th quantiles, which indicates strong information efficiency between two markets. It may suggest that investors in equity market take developments on the currency market seriously. On the other hand, when stock market is at more volatile state the exchange rate changes does not influence index dynamics.

Panel B of Table 3 contains the results from Poland. Auto-regressive components in the Panel A which measure level of inertia have positive sign, while exchange rate parameters have negative sign which is consistent with portfolio balance theory. The parameters of first AR lag are significant only at lower quantiles, indicating that investors consider information from stock market in previous period only when the stock market is relatively tranquil. Also, it can be seen that the effect is fading when market becomes more volatile. Probable reason could be the inability of investors to predict future movements on equity market when volatility increases. Likewise, it is worth noting that the impact from $\mathrm{AR}_{-1}$ component is lower at higher quantiles, which is in favor to the claim that market's activities mitigate when stocks report larger swings. Impact from AR component is lower and less significant in the time $\mathrm{t}-2$. On the other hand, ARDL model registers an exchange rate effect on stocks at the time $t$, but only at the lower quintiles. However, the constant impact from FX market to stock prices is reported at the first lag of the exchange rate at almost all levels of stocks volatility. Similar to autoregressive impact, it is noticeable that affect from exchange rate slowly declines with the rise of quantiles, which can be interpreted as more careful behavior of investors when stock market enters unstable phases. 
Živkov D. et al.: Exchange Rate Effect on Stock Returns in the East...

Table 3. The quantile regression estimates (Eq. (5))

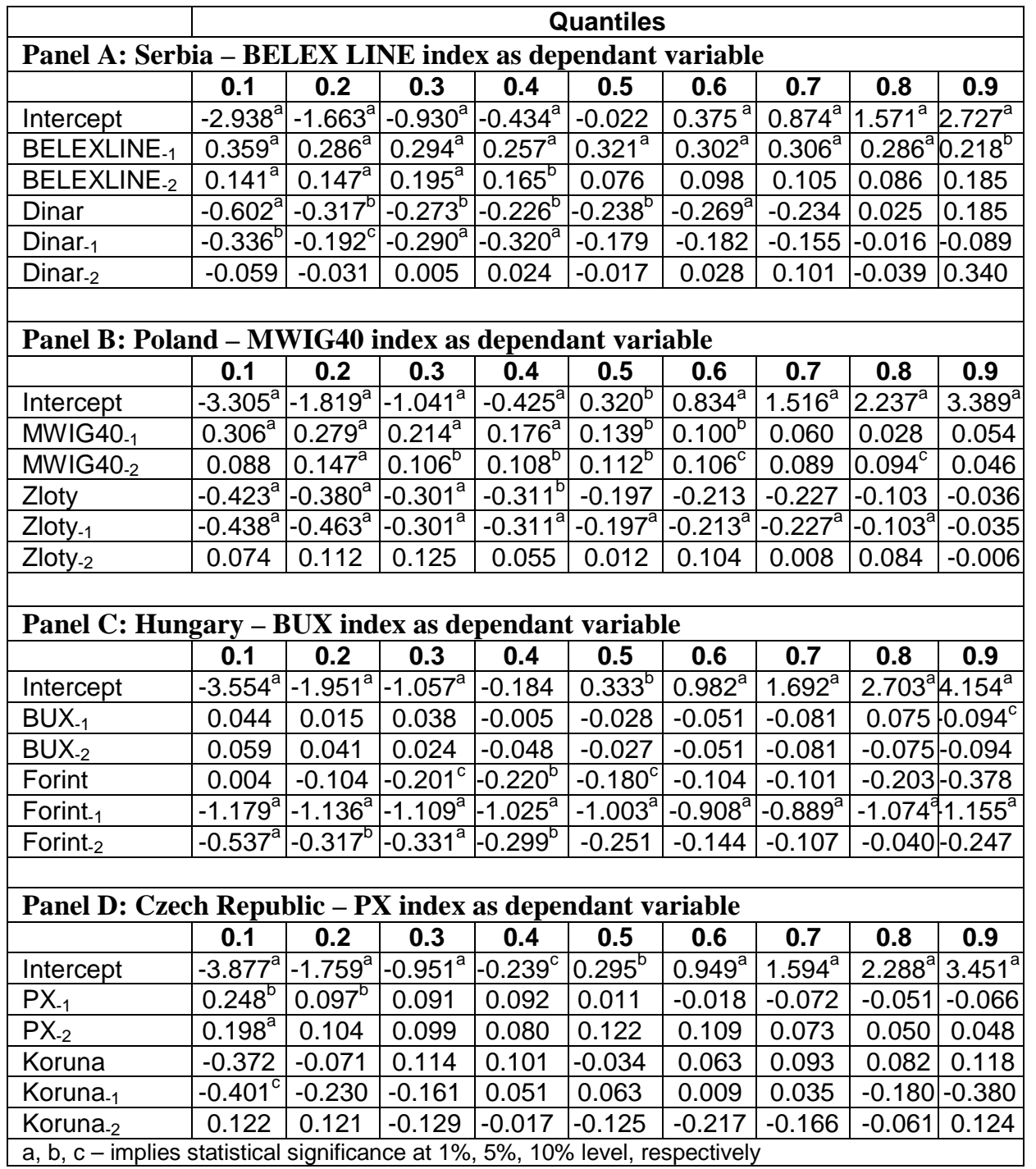

Source: Authors' calculation

As for Hungary, the effect from auto-regressive components is not found whatsoever. Possible reason could be the presence of more volatility in the Hungarian stock market compared to the Polish and Serbian counterpart (see Table 1). The importance of information from the previous period has little influence, which is probably, due to wild and frequent index changes, reflected 
Živkov D. et al.: Exchange Rate Effect on Stock Returns in the East...

by high kurtosis coefficient. The effect of the impact from the contemporaneous exchange rate is much weaker than in the Polish case. However, first and partially second leg of forint quantile regression estimates could represent clear evidence that shocks from exchange rate market are statistically insignificant. As in the case of Poland, contemporaneous effect from the exchange rate market is weak. However, the exchange rate changes in the time t-1 have very strong and persistent effect on the stocks in the current period, which is more than double comparing with Poland and Serbia. Quantile slope coefficients are almost constant in value, regardless to the level of stock market volatility. The influence from time $\mathrm{t}-2$ is much milder both in the level and the time of duration comparing to the $t-1$ period, but the impact is very sturdy. This could mean that shocks from the Hungarian foreign exchange market have a longer effect on the stock market than in the case of Poland and Serbia, but only during tranquil phases.

Situation on the Czech stock market is different comparing to the other three markets. Czech stock market reports high volatility, which is depicted in relatively high kurtosis coefficient, similarly to the case of Hungarian BUX index. That is probable reason why information from the previous period is weakly influential. Unlike the other three countries, Czech koruna has no effect on the PX index whatsoever. ADL model reports some influence at first quantile of first koruna lag, but with statistically insignificant probability. The results unequivocally suggest that information from the stock market in previous periods, as well as the information from the exchange rate market in the current and previous periods, have no influence on the Czech index. The results presented in Table 3 could help investors and portfolio managers interested in these markets to improve their understanding of relation between these two markets and eventually adopt adequate hedging strategies.

As complement analysis, authors estimate $\operatorname{ADL}(2,2)$ model with OLS and compare the results with the quantile regression findings. The purpose is to examine whether traditional estimation technique (OLS) is affected by the fat tails of unconditional distribution. If so, that would be another confirmation that usage of QR estimation procedure is justifiable. The results are reported in Table 4.

Table 4. $A D L(2,2)$ models estimated with OLS

\begin{tabular}{|l|c|c|c|c|c|c|}
\hline & $\mu$ & $r_{t-1}$ & $r_{t-2}$ & $S$ & $S_{t-1}$ & $S_{t-2}$ \\
\hline BELEX L. & 0.051 & $0.263^{\mathrm{a}}$ & $0.162^{\mathrm{a}}$ & $-0.224^{\mathrm{c}}$ & $-0.252^{\mathrm{b}}$ & 0.020 \\
\hline MWIG40 & $0.198^{\mathrm{c}}$ & $0.156^{\mathrm{a}}$ & $0.075^{\mathrm{c}}$ & $-0.259^{\mathrm{a}}$ & $-0.440^{\mathrm{a}}$ & -0.019 \\
\hline BUX & $0.348^{\mathrm{a}}$ & -0.031 & -0.047 & -0.108 & $-1.247^{\mathrm{a}}$ & $-0.363^{\mathrm{a}}$ \\
\hline PX & 0.150 & 0.019 & $0.082^{\mathrm{C}}$ & -0.155 & -0.161 & 0.222 \\
\hline
\end{tabular}

a, b, c - implies statistical significance at 1\%, 5\%, 10\% level, respectively

Source: Authors' calculation 
Živkov D. et al.: Exchange Rate Effect on Stock Returns in the East...

Comparing OLS estimates in Table 4 with the 5th quantile or median slope coefficient in Table 3, it could be seen that these estimates are different. The OLS estimates are biased in most cases due to leptokurtosis presence in the unconditional distribution, i.e. its values are higher comparing to median estimates in Table 3. Consequently, it means that OLS parameters are not adequate for deeper inference due to outliers and structural breaks presence because it would result in erroneous conclusions. These new findings vindicate the usage of QR inferential procedure.

Additionally, it is useful to see the results which were found by other researches on this topic in the observed countries. Grambovas (2003) reported the existence of strong link between foreign exchange market and stock market in Hungary, using weekly data from January 1994 to February 2000. Similarly to the authors' findings, no evidence was found of causality that ranges from foreign exchange market to stock market in the Czech Republic. Fedorova and Saleem (2010) also considered this topic using a bivariate GARCH-BEKK model and data span from January 1995 to December 2008. They documented unidirectional volatility spillover from currency markets to stock markets in Poland, Hungary and Russia. According to their findings, the relation goes in opposite direction in case of Czech Republic. Ulku and Demirci (2012) explained possible reason why in the case of Czech Republic causality direction runs from stock returns to exchange rate changes, and not vice versa. They argued that instantaneous co-movement of the exchange rate with the stock market depends on the depth of the stock market as well as on size of residents' equity portfolio flows abroad compared to the size of nonresidents' equity portfolio flows in the country. According to their research, if resident's equity portfolio outflow outbalances international investor's inflows, the relationship may change direction i.e. from stocks to exchange rate, as in the case of Czech Republic.

\section{Summary and conclusion}

Using weekly data (from January 2003 to June 2013) of the stocks and currencies in four East European countries (Serbia, Poland, Hungary and Czech Republic) authors investigate the relationship between these two markets utilizing quantile regression method. Due to the fact that time frame is relatively large and encompasses world crisis outbreak, viable assumption was that observed data have been polluted by structural breaks and heterogeneous conditional distribution. Using Bai and Perron (2003) technique of structural break detection, authors found structural changes in Serbia, Poland and Hungary. In such circumstances, in order to avoid parameters bias, quantile regression method has been applied, which proved to be robust in the presence of outliers and multiple structural breaks. 
Živkov D. et al.: Exchange Rate Effect on Stock Returns in the East...

The empirical results show that $\operatorname{ADL}(2,2)$ models fits the data well, which is corroborated by proper parameters sign and their significance. Authors found that $\mathrm{H}_{0}$ hypothesis has been confirmed in three out of four analyzing countries. In other words, the relationship between stocks and exchange rate corresponds to the portfolio balance theory in those countries. The results are in line with other researcher's findings. In Serbian stock market, first lag autoregressive parameters are all significant at relatively high level, which means that stock market information from the previous period considerably influences current index dynamics both in tranquil and erratic periods. Dinar/Euro exchange rate changes affect Serbian index contemporaneously, as well as at first lag. The contemporaneous effect is more intense comparing to first lag effect, and it is present up to 6th quantiles. In the Polish stock market, authors found considerable price inertia which is present in first and second lag of MWIG40 index but just at the lower quantiles. The first lag of Polish currency affect polish stocks at almost all quantiles. The similar influence is evident between Hungary stocks and Forint currency. However, neither autoregressive nor currency effect has been found in the case of Czech stock market. The findings revealed in this paper may benefit future investors interested in these emerging markets.

\section{References}

Bai, J., \& Perron, P. (2003). Computation and analysis of multiple structural change models. Journal of applied econometrics, 18(1), 1-22.

Caballero, R. J., Farhi, E., \& Gourinchas, P. O. (2008). An equilibrium model of global imbalances and low interest rates. American Economic Review, 98(1), 358393.

Fang, W. (2002). The effects of currency depreciation on stock returns: Evidence from five East Asian economies. Applied Economics Letters, 9(3), 195-199.

Fedorova, E., \& Saleem, K. (2010). Volatility spillovers between stock and currency markets: evidence from emerging Eastern Europe. Czech Journal of Economics and Finance, 60, 519-533.

Grambovas, C. A. (2003). Exchange rate volatility and equity markets. Eastern European Economics, 41(5), 24-48.

Koenker, R., \& Hallock, K. (2001). Quantile regression: An introduction. Journal of Economic Perspectives, 15(4), 43-56.

Liang, C. C., Lin, J. B., \& Hsu, H. C. (2013). Reexamining the relationships between stock prices and exchange rates in ASEAN-5 using panel Granger causality approach. Economic Modelling, 32, 560-563.

Lin, H. Y., \& Chu, H. P. (2013). Are fiscal deficits inflationary?. Journal of International Money and Finance, 32, 214-233.

Miles, W., \& Schreyer, S. (2012). Is monetary policy non-linear in Indonesia, Korea, Malaysia, and Thailand? A quantile regression analysis. Asian-Pacific Economic Literature, 26(2), 155-166. 
Živkov D. et al.: Exchange Rate Effect on Stock Returns in the East...

Moore, T., \& Wang, P. (2014). Dynamic linkage between real exchange rates and stock prices: Evidence from developed and emerging Asian markets. International Review of Economics \& Finance, 29, 1-11.

Phylaktis, K., \& Ravazzolo, F. (2005). Stock prices and exchange rate dynamics. Journal of International Money and Finance, 24(7), 1031-1053.

Savić, L., \& Bošković, G. (2011). Uticaj svetske ekonomske krize na razvoj Srpske industrije. Industrija, 39(4), 87-106.

Sula, O. (2011). Demand for international reserves in developing nations: A quantile regression approach. Journal of International Money and Finance, 30(5), 764-777.

Tai, C. S. (2007). Market integration and contagion: Evidence from Asian emerging stock and foreign exchange markets. Emerging Markets Review, 8(4), 264283.

Ülkü, N., \& Demirci, E. (2012). Joint dynamics of foreign exchange and stock markets in emerging Europe. Journal of International Financial Markets, Institutions and Money, 22(1), 55-86.

Walid, C., Chaker, A., Masood, O., \& Fry, J. (2011). Stock market volatility and exchange rates in emerging countries: A Markov-state switching approach. Emerging Markets Review, 12(3), 272-292. 